\title{
Flood mapping employing local, regional and global scale modeling methods for the Uruguay river
}

\author{
Métodos de modelagem de áreas inundadas utilizando técnicas de escala \\ local, regional e global para uma cheia no rio Uruguai
}

\author{
Maria Eduarda Pereira Alves' \\ Fernando Mainardi Fan" \\ Vinícius Alencar Siqueira"' \\ Leonardo Laipelt| ${ }^{\mathrm{V}}$
}

\begin{abstract}
The delimitation of flooded areas is important information for natural disaster management, environmental impact prediction and for territorial planning. Flooding occurs when water levels overflow the limits of a river's channel and seep into the floodplains. When they affect people, they are considered a natural disaster. The delimitation of a flooded area, in the occurrence of an extreme event, can be performed by using field techniques, such as mapping, surveying through the afflicted area or by taking aerial photographs. However, field survey is not a trivial task and not always does it allow for the attainment of the necessary data for a given project. For that purpose, there are various techniques that can be used to assess flood-spots. Some techniques are simpler, being based only on a Digital Elevation Model (DEM), and such is the case of the HAND model (Height Above Nearest Drainage), which has garnered plenty of fame recently in the process of applying delimitations to possibly flooded areas. Other techniques are more complex, like the use of hydrodynamic modeling. There are large-scale hydrologic-hydrodynamic models that simulate runoff generation and water transportation processes in the river basin from rainfall, basin, and meteorological data. This is the case of the large-scale distributed hydrological model called MGB (Modelo de Grandes Bacias), which has been developed and employed in these types of cases. However, there are no studies in the literature that compare the results produced by these multiple approaches using differing degrees of complexity and spatial scales. It was precisely to fill this gap in scientific literature that this work was developed. Featured here, for the first time, is the validation of the MGB model's performance in two versions, one of regional scale and another of continental scale (MGB AS), in delimiting the flooded areas, compared to a satellite image of the inundation; and with two versions of the HAND model, one generated by a local study and the other by a global reference. The case study used in this validation was a major flood that occurred in the Uruguay River, near the town of Itaqui (Rio Grande do Sul), which borders Brazil and Argentina, in October 1997. The results show that the MGB model, both in the regional and the continental scales, could delimit the flooded area, with a few overestimations in the northern portion of the image. The HAND method at the local scale also allowed a mapping of the flooded area, with overestimates for more springhead-like areas in small tributaries. The HAND method at the global scale, on the other hand, proved to be inadequate for the purpose of delimiting flooded
\end{abstract}

I Universidade Federal do Rio Grande do Sul, Porto Alegre, RS, Brasil - eduarda.alves@ufrgs.br..

II Universidade Federal do Rio Grande do Sul, Porto Alegre, RS, Brasil - fernando.fan@ufrgs.br.

III Universidade Federal do Rio Grande do Sul, Porto Alegre, RS, Brasil - vinisiquera@gmail.com.

IV Universidade Federal do Rio Grande do Sul, Porto Alegre, RS, Brasil - leolaipelt@gmail.com. 
areas in this region. The leading cause is believed to be the small drainage area threshold linked to the utilized global HAND product. From the calculation of performance metrics, like hit rate, false alarm ratio and criticality index, Regional MGB was the one that most adequately expressed the extent of the flood observed in the Landsat 5 image when compared to the others, followed by MGB AS.

Keywords: Flood mapping; Hydrodynamic modeling; Uruguay river.

\section{Resumo}

A delimitação de áreas inundadas é uma informação importante para a gestão de desastres naturais, previsão de impactos ambientais e planejamento territorial. Inundações ocorrem quando uma cheia ultrapassa os limites da calha de um rio e escoa para as planícies de inundação. Quando estas atingem pessoas, elas são consideradas um desastre natural. A delimitação da cheia observada dada a ocorrência de um evento extremo pode ser feita através de técnicas de campo, como o mapeamento percorrendo a área afetada ou utilizando aerofotos. Todavia, o levantamento em campo não é trivial e nem sempre permite a obtenção do dado necessário para um projeto específico. Para este fim, existem múltiplas técnicas para estimativa de manchas de inundação. Algumas são técnicas mais simplificadas, baseadas apenas em um Modelo Digital de Elevação (MDE). Este é o caso do modelo HAND (Height Above Nearest Drainage), que tem ganhado muita fama recentemente na aplicação de delimitação de áreas possivelmente inundadas. Outras técnicas são mais complexas, como o uso de modelagem hidrodinâmica. Nesta linha, existem modelos hidrológicohidrodinâmicos de grande escala que simulam processos de geração de escoamento e de transporte de água na bacia hidrográfica a partir de dados de chuva, meteorológicos e de características da bacia hidrográfica. Este é o caso do MGB (Modelo de Grandes Bacias), que vem sendo desenvolvido e aplicado para estes tipos de caso. Todavia, não existem trabalhos na literatura que comparem resultados gerados por estas múltiplas abordagens com diferentes graus de complexidade e diferentes escalas espaciais. Exatamente para preencher esta lacuna existente na literatura científica que este trabalho foi desenvolvido. É apresentada aqui, pela primeira vez, a verificação do desempenho do modelo MGB em duas versões, uma de escala regional e outra de escala continental para a delimitação de áreas inundadas, em comparação com uma imagem de satélite observada da cheia e com duas versões do modelo HAND, uma gerada por um estudo local e outra gerada por um estudo global. O estudo de caso utilizado na verificação foi uma cheia que ocorreu no Rio Uruguai, nas proximidades da cidade de Itaqui (RS), que faz divisa entre os países Brasil e Argentina, em outubro de 1997. Os resultados mostraram que tanto o modelo MGB aplicado em escala regional quando o modelo MGB em escala continental foram capazes de delimitar a área inundada, com algumas superestimativas na porção norte da imagem. O método HAND de escala local também permitiu um mapeamento da área inundada, com áreas mais de cabeceira de pequenos afluentes superestimadas. Já o método HAND em escala global demonstrou ser inadequado para aplicação para a delimitação de áreas inundadas nesta região. Acredita-se que a principal causa seja o pequeno limiar de área de drenagem relacionado com o produto HAND global utilizado. Verificou-se também, a partir do cálculo de métricas de desempenho, como taxa de acerto, de falso alarme e índice crítico, que o MGB Regional representou de maneira mais adequada a extensão da inundação observada na imagem Landsat 5 em comparação as demais metodologias, seguida pelo MGB AS.

Palavras-chave: Áreas inundadas; Modelagem hidrodinâmica; Rio Uruguai. 


\section{Introduction}

Flooded areas are regions that are submerged due to the overflowing of a river beyond its channel's limits, occupying the range known as floodplains which surround watercourses. River flooding is different from local urban flooding's in that the last ones happen due to the build-up of water by surpassing a local drainage system's capacity, especially in urban areas (CPRM, 2017). Flooding occurs mainly due to increased outflow in rivers, brought about by precipitation in the river basin, which generates larger superficial runoff to be drained into the channels. Especially the occurrence of precipitation with a high Recurrence Interval (RI) tends to also cause overflows with high RIs. Although a precipitation's RI is not necessarily the same as an overflow's, since the response of a basin in relation to a rain is non-linear and depends on variables such as the preceding soil moisture conditions. In addition, notably in large basins, flooding's that reach a given point can be linked to heterogeneous precipitation or to an instance of increased outflow in tributaries within the basin (FLEISCHMANN et al., 2019).

Floods may also happen or be compounded by other factors such as, for example, the operation of hydraulic structures (like the opening of reservoir hatches) or even the breaking of dams (TSCHIEDEL \& PAIVA, 2018). Other phenomena that can heighten the occurrence of overflows are the tide or wind effects in estuarine and/or large river regions (LOPES et al., 2018). Floods are a natural phenomenon and should not necessarily be considered natural disasters when they occur. A flood is only to be truly considered a natural disaster when its occurrence wreaks injury upon society, such as material damage or losses of life (KOBIYAMA M. et al., 2010). Aside from potential natural disaster, there are also other environmental factors that pertain to the importance of flooded areas, such as the incidence of fish spawning habitats, nutrient-rich sediment deposition, overflow buffer zones, high levels of water evaporation to the atmosphere, among others (PONTES et al., 2017).

Following this line of thinking, the delimitation of river flooded areas, chiefly in urban or other regions where property damage may be extensive (such as agricultural areas), becomes a crucial tool for land management and decision-making in the environmental field. After an overflow, this delimitation can be carried out on-site, through comprehensive 
fieldwork of mapping or interviewing local inhabitants. Paixão et al. (2018) provide an example of this sort of survey. The trouble with this type of delimitation is that technical teams are required and that some of the locations may be inaccessible or at risk. An alternative, in this case, would be the to conduct the surveys using plane or drone aerial imaging. However, this second hypothesis may be restricted by the requirement of financial resources, availability of equipment, or by rainy weather itself during the survey.

Alternatively, to field surveying, the collection of the flood-spot can be done through remote sensing images, obtained through orbital sensors, which map the land surface with optical (passive) or radar (active) images. In case the satellite passed by the flooded region at the time of the occurrence, it is possible to process its image to obtain the water mask of the flooded area, which will be used in environmental studies. In fact, this is a very common option and is used by many studies such as Townsend (2001); Mengue et al., (2016); Garrafiel (2018); Zhang, Zhu \& Liu (2014). The major hindrance when using this approach is related to cloud coverage (which prevents the attainment of optical images) and to the requirement of image processing procedures in order to extract the mask. Aside from the fact that the passing of the satellite over the target area must coincide with precisely the moment of the flood.

Therefore, it is not always possible to obtain the necessary images of a flood through fieldwork or satellites, which are required for environmental studies or for the delimitation of areas possibly affected by a disaster, for example. Due to this difficulty, there is a wide range of flooded area delimitation techniques that were developed over the last decades for the purpose of estimating flooded areas from other information. Some of the techniques are simple and require only a digital elevation model (DEM) and an observed value of flood quota to be used. This is the case of those based on the HAND model (Height Above Nearest Drainage). Other techniques are more complex, making use of mathematical equations for the modeling of flood wave propagation in rivers and for the attainment of the associated flooded area.

Of the modeling variety, especially for large river basins, one of the most used in South American territory is called MGB (Large-Scale Distributed Hydrological Model), developed by Collischonn \& Tucci (2001) and refined over the last years by a series of 
researchers (PAIVA et al., 2013; FAN \& COLLISCHONN, 2014; FLEISCHMANN, SIQUEIRA, COLLISCHONN \& FAN, 2015; PONTES et al., 2017). Large-scale basins pose specific challenges in regard to mapping flooded areas, since there are various processes operating simultaneously to cause the flood, such as the runoff itself near flooded areas, rainfall with different TRs occurring heterogeneously across the basin, influx of water from multiple tributaries; as well as evapotranspiration, infiltration, tide effects, and even the wind on the water surface.

Even with these difficulties, the MGB model has been applied with relative success across all these kinds of cases, as shown by the works of Alves, Fan \& Fleischmann (2019); Neto, Dornelles, Fleischmann \& Medeiros (2019); Fleischmann, Collischonn \& Paiva (2018); Kuwajima et al. (2019); Lopes et al. (2018); Tschiedel \& Paiva (2018). Furthermore, in the study of Siqueira et al. (2018), the model was used for the entire South American territory, with the capacity to generate flood-spots for the whole area, from a 500m DEM of the SRTM - Shuttle Radar Topography Mission (FARR et al., 2007).

Despite such wide usage, there are no studies in the literature comparing the MGB model's capability of simulating flooded areas with other, more local and simpler modeling tools. Comparing, for example, to results based on the HAND - Height Above Nearest Drainage terrain descriptor (RENNÓ et al., 2008; NOBRE et al., 2011), which has previously been used on occasion to delimit flooded areas, as in the work of Mengue et al. (2016); Goerl et al. (2017); Speckhann (2015); Dantas \& Canil (2017); and Milanesi, Quadros \& Lahm (2017).

Thus, it is with the aim of filling this gap in scientific literature that this work was developed. Featured here, for the first time, is the validation of the MGB model's performance across two versions, one of regional and the other of continental scale (SIQUEIRA et al., 2018), for the delimitation of flooded areas, compared to a satellite image of the overflow; and two versions of the HAND model, one generated by a local study (MENGUE, SCOTTÁ, SILVA \& FARINA, 2016) and the other by a global one (DONCHYTS et al., 2016). The case study used for the validation was a major flood that occurred in the Uruguay River, in the vicinity of the town of Itaqui (Rio Grande do Sul), which borders Brazil and Argentina, in October 1997. The Planetary Boundary Layer (PBL) is the layer adjacent to the surface, where turbulent heat and momentum transport occurs throughout the order of 
an hour and with vertical resolution about $1 \mathrm{~km}$, it has atmospheric processes due to the thermal and mechanical convection during daytime and suppressed turbulent conditions that persist and evolve during the nighttime. The daily cycle of PBL varies according to the heating of the Earth's surface according to the incident solar radiation, which consists usually of a convective phase during the day (Convective Boundary Layer - CBL) and a stable phase at night (Nocturnal Boundary Layer - NBL). Therefore, studies of atmospheric processes in the lower troposphere have an important impact on society and the environment, since they occur within the PBL which is where most of the people live.

One of the fundamental parameters in PBL studies is the determination of its height, since its depth is a measure of the intensity of the surface-atmosphere interaction, in addition to being an important parameter for atmospheric modeling (NEVES; FISCH, 2015). However, the logistics for PBL height observations are often complicated. Consequently, methods to estimate its height from numerical simulations are important, and with the advancement of computational resources it has allowed improvements in modeling to solve the different scales of turbulence.

Therefore, this work has the objective to evaluate the applicability of a large scale numerical vortex model, called PALM (PArallelized Large-Eddy Simulation Model), developed by the University of Hannover in Germany and described in Raasch and Schröter (2001) and Maronga et al. (2020), in CBL simulations comparing with observational data (radiosonde and ceilometer), in an one day representative of the rainy and dry seasons in the Central Amazon region.

\section{Material and Methods}

The proposed methodology to achieve the goals set out by this work consists of the comparison of both MGB (Modelo de Grandes Bacias) versions' results, one at regional scale (ALVES, 2018) and the other at continental scale (SIQUEIRA et al., 2018); and of results of the HAND method (Height Above Nearest Drainage) performed from two different independent sources, one on a local scale (MENGUE, SCOTTÁ, SILVA \& FARINA, 2016) and the other source on a global scale (DONCHYTS et al., 2016). The results of these four methods were 
used for comparison with the major river flood that happened in October 1997 in the Uruguay River, on the border between Brazil and Argentina, whose observed flooded area was extracted from an image captured by the Landsat 5 satellite. The study area and each of the employed models and methods are hereafter explained in detail.

\subsection{Study Area}

The study area that was used in the comparison is featured in Figure 1. It consists of the surrounding polygon from the region's Landsat 5 satellite image where the overflow was observed, near the town of Itaqui (RS, Brazil). The main river, which runs north-south in the main portion of the image, corresponds to the Uruguay River. In the southern section of the image, the Ibicuí River (which runs East-West) is another great river which also flooded at the time. The water mask presented in Figure 1 was derived from a Landsat 5 image using an NDVI filter (GAO, 1996).

Figure 1 - Study area location, with the observed flood-spots already marked, processed from the Landsat 5 satellite

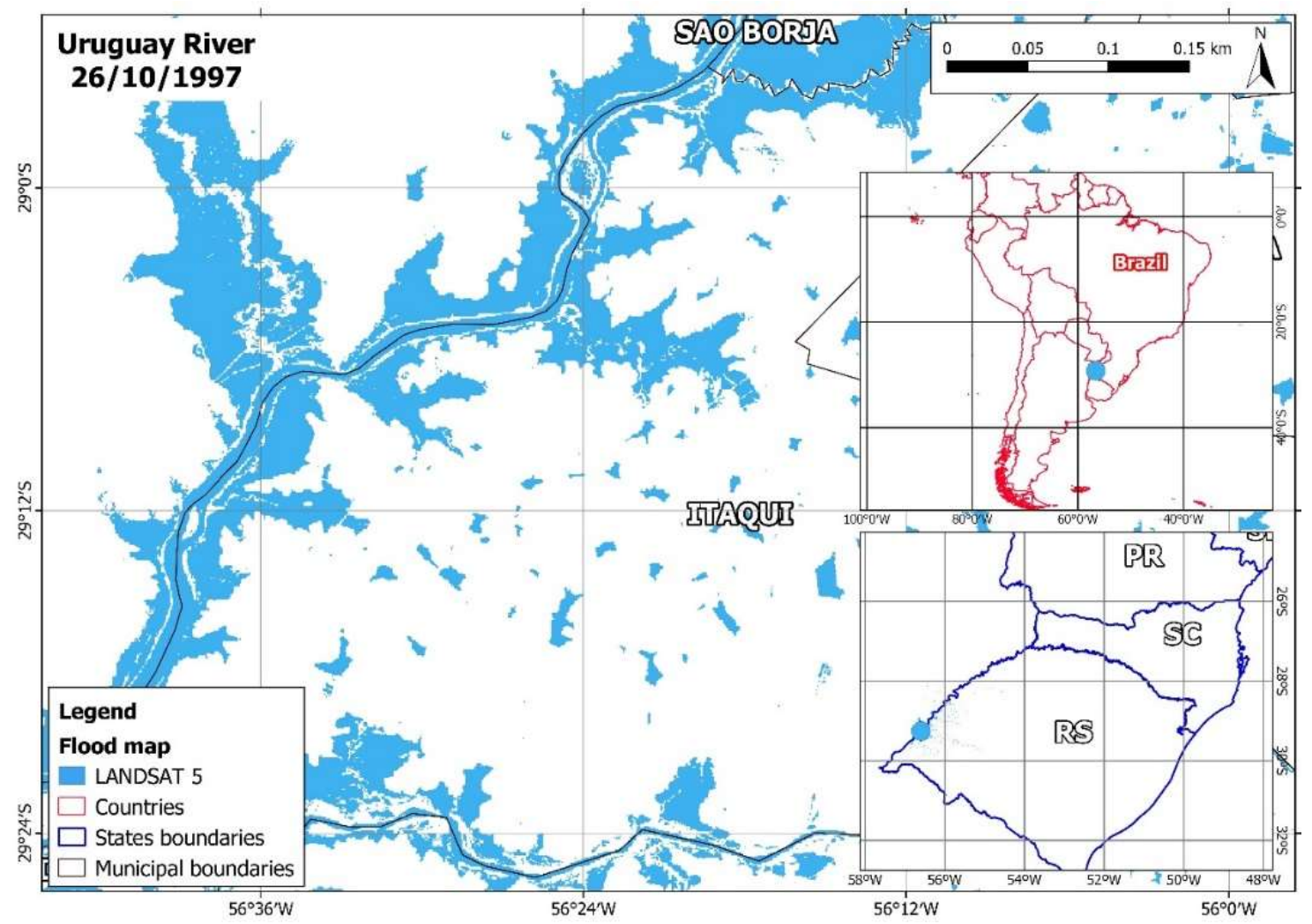




\subsection{MGB at regional scale}

The MGB is a semi-distributed hydrologic-hydrodynamic model, which simulates the river basin by subdividing it into smaller units, called catchments. It replicates the surface water balance in the soil and the subsoil through a linear reservoir approach, evapotranspiration through Penman-Monteith (MONTEITH, 1965), and runoff propagation using the local inertia propagation approximation. More details about the current version of the model can be found at Pontes et al. (2015).

The regional scale MGB that was used in this study is the same model that was utilized by Alves, Fan \& Fleischmann (2019), which presented the hydrologic-hydrodynamic model for the entire Rio Grande do Sul Hydrological (RSH) territory, with satisfying results. The model was calibrated for the 2000 to 2010 period and validated for the period between 1990 to 2000. Table 1 presents the results of this hydrologic calibration for the Passo São Borja (75780000), Itaqui (75900000) and Uruguaiana (77150000) stations, which are the Uruguay river analysis stations, respectively located upstream, in the town, and downstream of the study area. The results of the Nash-Sutcliffe efficiency coefficient (NASH \& SUTCLIFFE, 1970) and average runoff error (volume error - VE) are also shown. In the conception of the model, a 90m processed resolution SRTM DEM was used to remove the vegetation, known as Bare Earth SRTM (O'LOUGHLIN, PAIVA, DURAND, ALSDORF \& BATES, 2016).

Table 1 - Regional MGB model performance applied to the river analysis stations in the study area

\begin{tabular}{|c|c|c|c|}
\hline $\begin{array}{c}\text { Station ANA } \\
\text { code }\end{array}$ & Station name & $\begin{array}{c}\text { NSE calibration/ } \\
\text { validation }\end{array}$ & $\begin{array}{c}\text { VE calibration/ } \\
\text { validation (\%) }\end{array}$ \\
\hline 75780000 & $\begin{array}{c}\text { Passo São } \\
\text { Borja }\end{array}$ & 0.88 & 5.8 \\
\hline 75900000 & Itaqui & 0.63 & 10.4 \\
\hline 77150000 & Uruguaiana & 0.85 & -8.7 \\
\hline
\end{tabular}

\subsection{MGB at continental scale}

The continental scale MGB employed in this research is the same model that was arranged by Siqueira et al. (2018), which calibrated the hydrologic-hydrodynamic model for 
the entire South American territory. The model was calibrated for the period of 2000 to 2010 . Table 2 displays the calibration results of this model for the Passo São Borja (75780000) and Uruguaiana (77150000) stations. Itaqui station (75900000) was not used for calibration and validation in the work of Siqueira et al. (2018). The HydroSHEDS 500m SRTM DEM was used for the conception of this model (LEHNER, VERDIN \& JARVIS, 2008).

Table 2 - Continental MGB model performance applied to the river analysis stations in the study

\begin{tabular}{|c|c|c|c|}
\hline $\begin{array}{c}\text { Station ANA } \\
\text { code }\end{array}$ & Station name & $\begin{array}{c}\text { NSE calibration/ } \\
\text { validation }\end{array}$ & $\begin{array}{c}\text { VE calibration/ } \\
\text { validation (\%) }\end{array}$ \\
\hline 75780000 & Passo São Borja & 0.83 & 2.77 \\
\hline 77150000 & Uruguaiana & 0.80 & 4.69 \\
\hline
\end{tabular}

\subsection{HAND at local scale}

The local scale HAND model that was approached in this work was arranged by Mengue et al. (2016). The authors tested several configurations of the HAND model and concluded that the one used in this study best represents the 1997 overflow in the Uruguay River, in Itaqui. This HAND was arranged from the 90m SRTM DEM, with the drainage area's starting threshold at 10 thousand cells and reclassified to the $11.5 \mathrm{~m}$ quota, which coincides with the flood quota that reached the town, to generate information on the flooded area.

\subsection{HAND at global scale}

The global scale HAND model used in the present study was the one prepared by Donchyts et al. (2016). The researchers ran the HAND processing for the entire terrestrial globe from the 30m SRTM DEM, with the drainage area threshold at 5 thousand cells. This global HAND is available in the Google Earth Engine tool (at https://code.earthengine.google.com/0f734fda32464b92ba0b7fbd9b8b408b). It was reclassified for the $11.5 \mathrm{~m}$ quota, which coincides with the flood quota that reached the town, thus following the same pattern used in the local scale HAND that was tested. 


\subsection{Comparison and analyses}

Every result generated by the hydrologic-hydrodynamic modeling and the selected HAND methods were compared to the delimitation of the observed flooded area's Landsat 5 image. The results were analyzed in terms of overflow representation capacity and discussed under the lens of the limitation of each approach.

The extent of the flood was also evaluated for each and every configuration in relation to the observed overflow's Landsat 5 image, following the same approach as Hoch \& Trigg (2019), through the $\mathrm{H}$ hit rate, $\mathrm{F}$ false alarm ratio and the $\mathrm{C}$ critical success index, represented in equations 1,2 and 3 , respectively.

$$
\begin{gathered}
H=\frac{N_{\text {sim }} \cap N_{o b s}}{N_{o b s}} \\
F=\frac{N_{\text {sim }} / N_{o b s}}{N_{\text {sim }} \cap N_{o b s}+N_{\text {sim }} / N_{o b s}} \\
C=\frac{N_{\text {sim }} \cap N_{o b s}}{N_{\text {sim }} \cup N_{o b s}}
\end{gathered}
$$

Whereas Nobs and Nsim respectively indicate the number of flooded cells according to the result and observations of the examined simulation. The indices vary from 0 to 1 , where the closer $\mathrm{H}$ and $\mathrm{C}$ are to 1 , the better the flooded extension's representation is; and the closest $F$ is to 0 , the less errors are presented in flooding estimates.

\section{Results and Discussion}

Figures 2 through 5 present the obtained results for each of the study's experiments. In all cases, the blue spot represents the one modelled by its respective tested method (regional MGB, continental MGB, local HAND and global HAND), and the black polygons represent the flooded areas that were delimited from the Landsat 5 satellite images. 
Figure 2 - Regional MGB model results compared to the satellite image of the October 1997 overflow in the Uruguay River

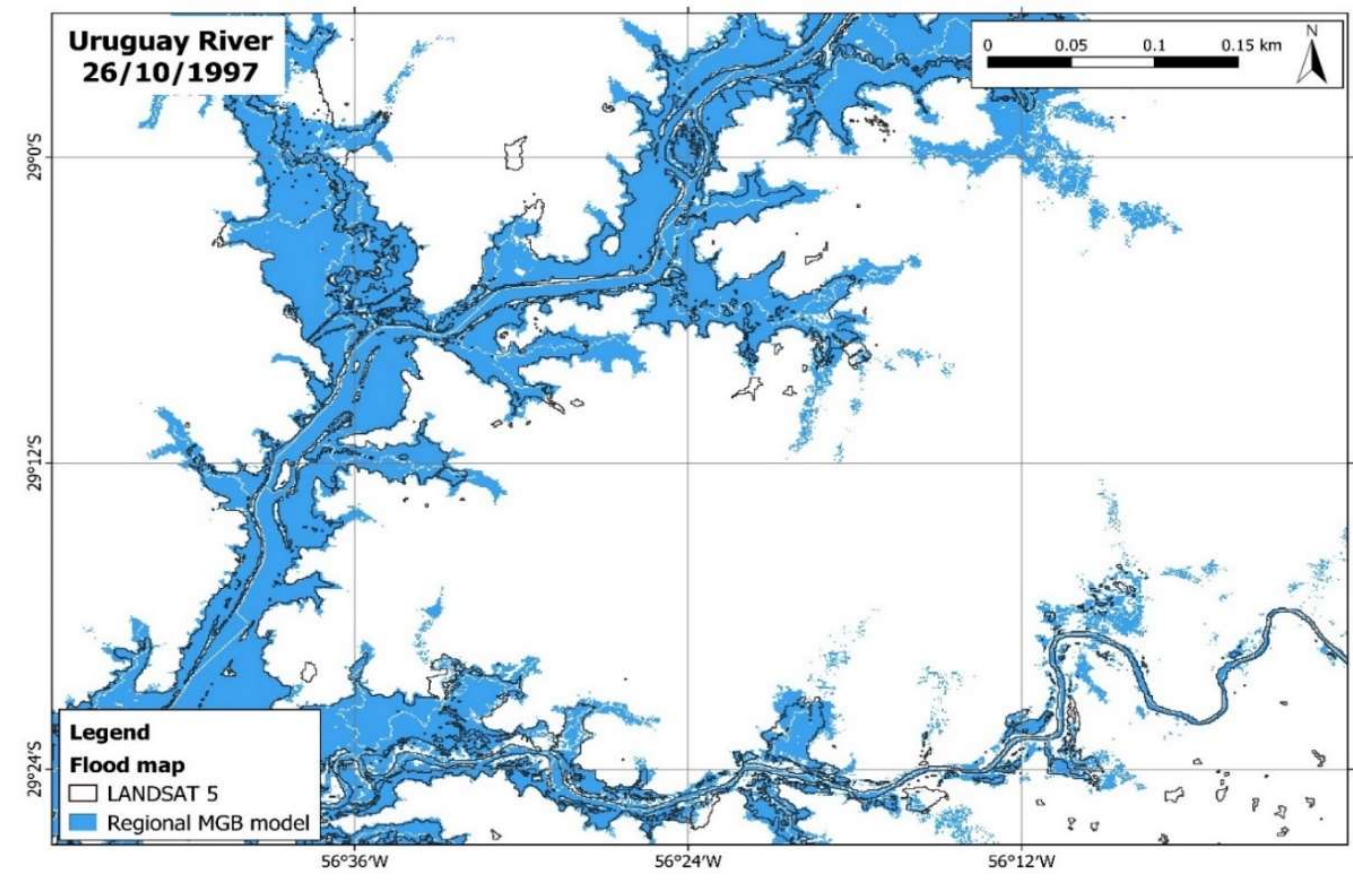

Figure 3 - Continental MGB model results compared to the satellite image of the October 1997 overflow in the Uruguay River

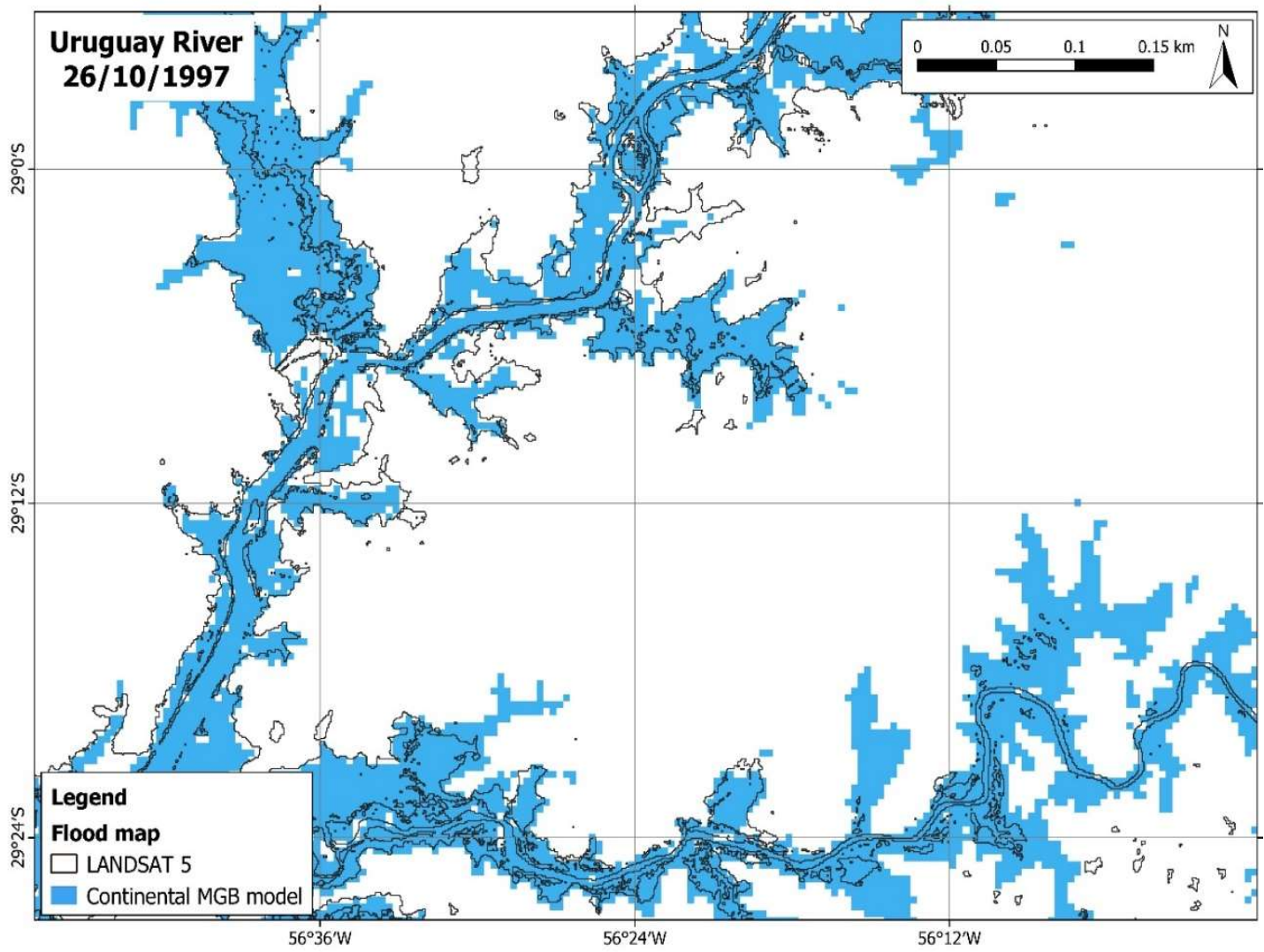


Figure 4 - Local HAND method results compared to the satellite image of the October 1997 overflow in the Uruguay River

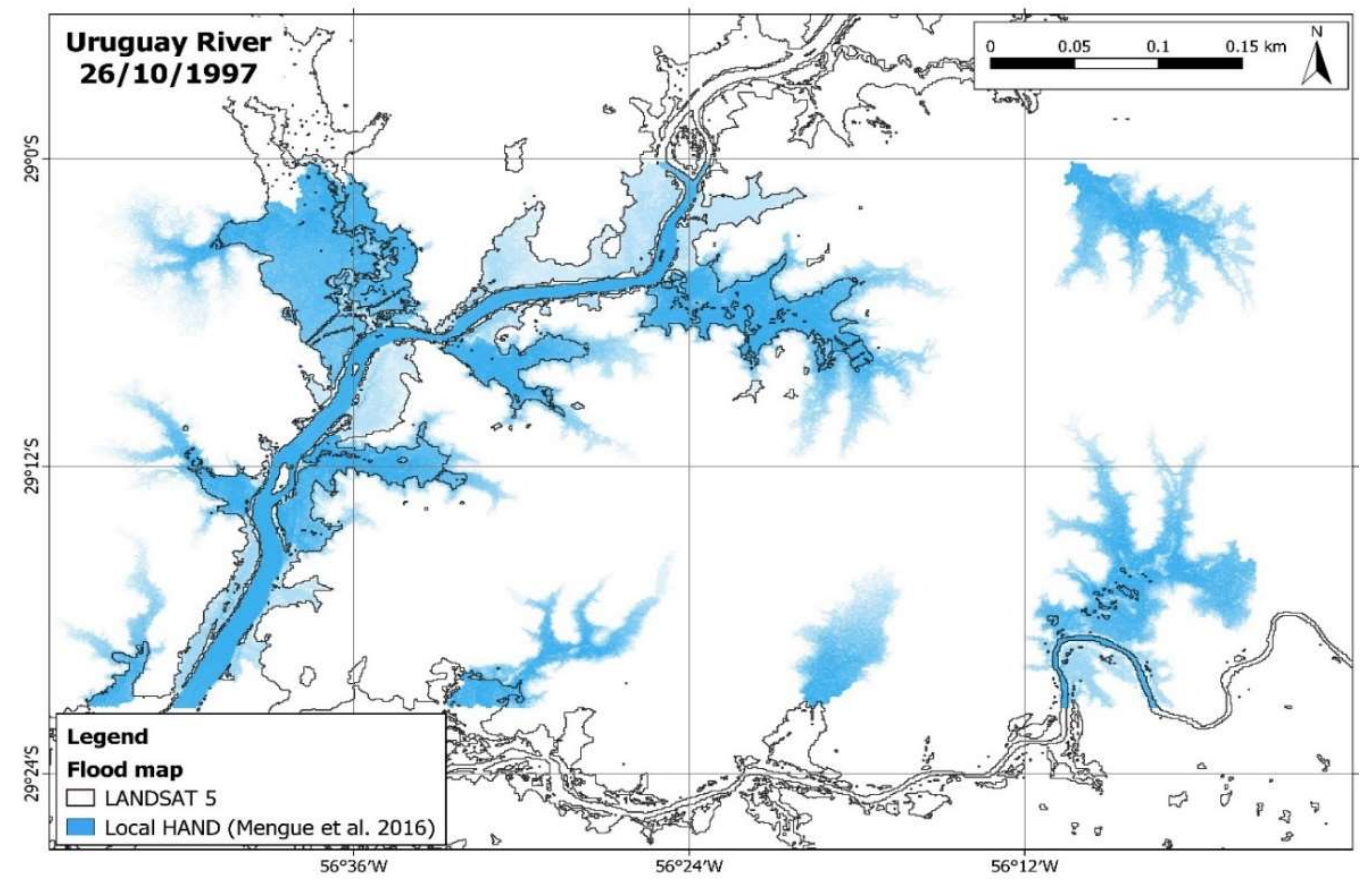

Figure 5 - Global HAND method results compared to the satellite image of the October 1997 overflow in the Uruguay River

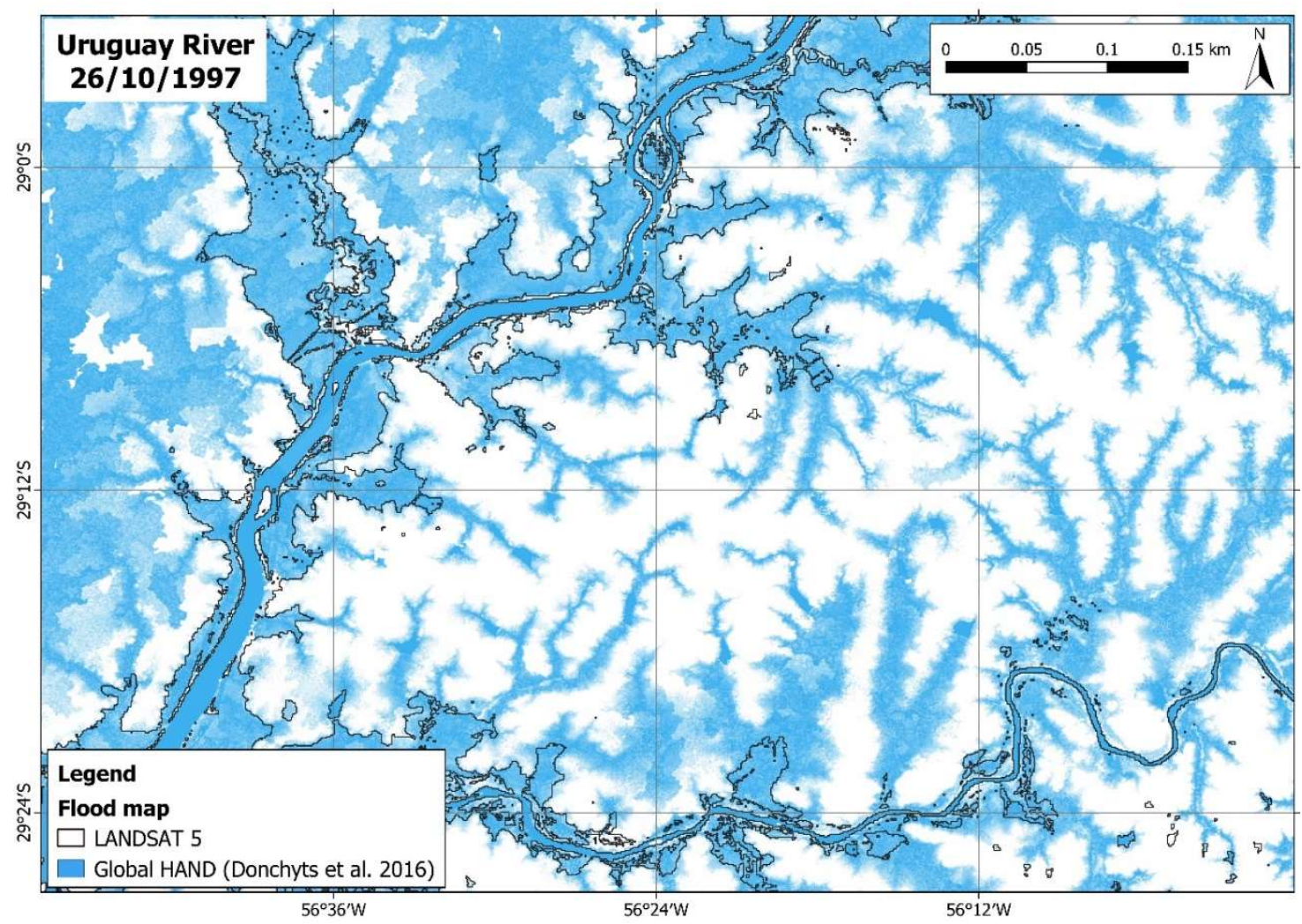


A visual analysis of the results reveals that the modeling performed with the MGB model at regional scale tends to map every flooded area in the main river with considerable accuracy, with some more noticeably overestimated areas especially in the northern portion of Figure 2. The same can be said about Continental MGB's results, exempting the noticeable effect of the continental model's coarser resolution $(500 \mathrm{~m})$, in addition to some areas that were underestimated within the main river, and overestimated areas in the basin's southern fraction, which is a region of the lbicuí River.

In the case of the local HAND, one notices that the flooded areas in the main river are also well demarcated. However, there are some deficiencies in the central portion of the main river, with significant overestimation in the more springhead-like segments of the small flooded tributaries. This occurs at several points of the image, as can be observed in Figure 4. Unfortunately, the local HAND model employed by Mengue et al. (2016) and used thus far does not allow comparisons for the lbicuí River, since this area is not included in the work that carried out the original application of the model.

Now in the case of global HAND, its tendency to exaggerate the delimitation of flooded areas is noticeable, unlike the other methods that were tested. In this case, visual analysis highlights that HAND's global database established from a 30m DEM, with 5 thousand cells of drainage area threshold (DONCHYTS et al., 2016), is not adequate for mapping flooded areas in this region. The exaggeration of flooded areas is probably caused by the small drainage area threshold, from which the product was developed, leading to the overestimation of the presence of watercourses in the region. For more discussions on the importance of defining the starting drainage area threshold, we suggest reading the work of Fan et al. (2013).

Regarding the metrics, such as the $\mathrm{H}$ hit rate, the $\mathrm{F}$ false alarm ratio and the $\mathrm{C}$ critical success index (HOCH \& TRIGG, 2019), Table 3 features the attained results. All applications were then compared to the spot observed by the Landsat 5 satellite. We underline the fact that every small area corresponding to the previously mentioned reservoirs was deleted for metric calculations, and that every metric was gauged for the bounding rectangle of Mengue et al. (2016). 
Table 3 - Performance metrics for the analysis of the obtained flood extensions

\begin{tabular}{|c|c|c|c|}
\hline Spot & H & F & C \\
\hline MGB REG & 0.95 & $2.78 \mathrm{E}-06$ & 0.67 \\
\hline MGB AS & 0.74 & $3.17 \mathrm{E}-06$ & 0.51 \\
\hline HAND Mengue & 0.90 & $4.63 \mathrm{E}-06$ & 0.40 \\
\hline HAND Global & 0.99 & $8.76 \mathrm{E}-06$ & 0.22 \\
\hline
\end{tabular}

One could observe that, concerning the $\mathrm{H}$ index, which represents the flood extension hit rate, that is, how much of the observed spot is flooded by the simulated spot; the models that best represented it were the Global HAND and regional MGB. However, as featured on Figure 5, the Global HAND floods several areas, which is the reason why it presents a high $\mathrm{H}$ index. Thus, is the importance of analyzing the three metrics conjointly $(H, F$ and $C)$. With respect to the $\mathrm{F}$ false alarm ratio, the models that best depicted the observed spot were the Regional MGB and MGB AS, indicating that they were the ones that least indicated flooded areas where there were none in the Landsat 5 image. When analyzing the $C$ critical index, one can confirm that those that best represented the flooded extension were the regional MGB and MGB AS models.

\section{Final Considerations}

This study sought, for the first time in the literature, to undertake a performance validation of two versions of the MGB model, one at regional scale and the other at continental scale, for the delimitation of flooded areas; compared to two versions of the HAND model, one developed by a local study (MENGUE, SCOTTÁ, SILVA \& FARINA, 2016) and the other generated by a global study (DONCHYTS et al., 2016). These four methods were then compared to an observed satellite image of the overflow. The case study used in this validation was an overflow that occurred in the Uruguay River, near the town of Itaqui (Rio Grande do Sul), which borders Brazil and Argentina, in October 1997. The comparisons were made visually and by calculating performance metrics such as hit rate, false alarm ratio and critical success index, which granted the following conclusions:

- The MGB model applied at both the regional and the continental scale were 
considered capable of delimiting the flooded area, with some overestimates in the northern section of the image. Especially in the case of the continental model, some overestimates were also perceived in the image's southern section, as well as underestimates in a stretch of the main river.

- The local scale HAND model also provided an adequate mapping of the flooded area. The results were similar along the main river to the MGB versions, though, in springhead-like segments of small tributaries, HAND presented overestimations of flooded areas in a more prominent manner than the hydrologic-hydrodynamic models.

- However, the global scale HAND method proved to be the least adequate for the delimitation of the flooded areas in this region. The main cause for this shortcoming is the small drainage area threshold tied to the available global product that was used.

- Lastly, based on the metrics that were calculated, Regional MGB was the model that best represented the extent of the flood that occurred in October 1997 in the Uruguay River, near the town of Itaqui (Rio Grande do Sul), followed by MGB AS.

Future work in this field will include analyses of other major floods, as well as further study areas.

\section{Acknowledgements}

The authors would like to thank CNPq, CAPES and ANA (National Water Agency) for the received support, which made this research possible.

\section{References}

ALVES, M. E. (2018). SIMULAÇÃO DE ROMPIMENTO DE BARRAGENS EM CASCATA COM O MODELO MGB. TRABALHO DE CONCLUSÃO APRESENTADO AO CURSO DE ENGENHARIA AMBIENTAL DA UNIVERSIDADE FEDERAL DO RIO GRANDE DO SUL. Porto Alegre, RS, 2018.

ALVES, M. E.; FAN, F. M.; FLEISCHMANN, A. S. SIMULAÇÃO DE ROMPIMENTO DE 
BARRAGENS EM CASCATA COM O MODELO MGB. XXIII SIMPÓSIO BRASILEIRO DE RECURSOS HIDRÍCOS - ABRH, 2019.

COLLISCHONN, W.; TUCCI, C. E. Simulação Hidrológica de Grandes Bacias. RBRH - Revista Brasileira de Recursos Hídricos, 95-118, 2001.

CPRM. Curso de Capacitação de Técnicos Municipais para Prevenção e Gerenciamento de Riscos de Desastres Naturais. Vitória, ES, Brasil: Processos hidrológicos, 2017.

DANTAS, C. G.; CANIL, K. Identificação e mapeamento de áreas suscetíveis a inundação na bacia do Aricanduva - SP utilizando o algoritmo descritor de terreno HAND. ANAIS SIMPÓSIO BRASILEIRO DE GEOGRAFIA FÍSICA APLICADA, 10 p., 2017.

DONCHYTS, G.; WINSEMIUS, H.; SCHELLEKENS, J.; ERICKSON, T.; GAO, H.; SAVENIJE, H.; GIESEN, N. V. Global $30 \mathrm{~m}$ Height Above the Nearest Drainage. Proceedings of the EGU General Assembly, 17-22, 2016.

FAN, F. M.; COLLISCHONN, W. Integração do Modelo MGB-IPH com Sistema de Informação Geográfica. RBRH - Revista Brasileira de Recursos Hídricos, 243-254, 2014.

FAN, F. M.; COLLISCHONN, W.; SORRIBAS, M. V.; PONTES, P. R. Sobre o Início da Rede de Drenagem Definida a Partir dos Modelos Digitais de Elevação. Revista Brasileira de Recursos Hídricos, v. 18, 241-257, 2013.

FARR, T. G.; ROSEN, P. A.; CARO, E.; CRIPPEN, R.; DUREN, R.; HENSLEY, S.; BURBANK, D. The Shuttle Radar Topography Mission. Reviews of Geophysics. v. 45, 2007.

FLEISCHMANN, A. S.; COLLISCHONN, W.; PAIVA, R. Integrando reservatórios e planícies de inundação para a simulação de cheias em grandes bacias: aplicação na bacia do rio Itajaí-Açu. Anais do I Encontro Nacional de Desastres, 2018.

FLEISCHMANN, A. S.; SIQUEIRA, V. A.; COLLISCHONN, W.; FAN, F. M. Desenvolvimento Do Módulo De Reservatórios Do Modelo Hidrológico MGB-IPH. XXI Simpósio Brasileiro de Recursos Hídricos, 2015.

FLEISCHMANN, A.; BRÊDA, J. P.; FAN, F.; WONGCHUIG, S.; COLLISCHONN, W.; KAZAY, D. F.; MUSSI, K. UM MODELO HIDROLÓGICO-HIDRODINÂMICO DA BACIA DO PARANÁ E SEUS RESERVATÓRIOS. XXIII SIMPÓSIO BRASILEIRO DE RECURSOS HIDRÍCOS - ABRH, 2019.

GAO, B. C. NDWI-A normalized difference water index for remote sensing of vegetation liquid water from space. Remote sensing of environment, 257-266, 1996.

GARRAFIEL, G. F. MAPEAMENTO DE INUNDACOES URBANAS A PARTIR DE IMAGENS DE RADAR DE ABERTURA SINTETICA DO PROGRAMA SENTINEL. Trabalho de conclusão de curso em Engenharia Ambiental. Porto Alegre, RS: UFRGS, 2018. 
GOERL, R. F.; CHAFFE, P. L.; SPECKHANN, G. A.; PELLERIN, J. R.; FLORES, J. A.; ABREU, J. J.; SANCHEZ, G. M. O MODELO HAND COMO FERRAMENTA DE MAPEAMENTO DE ÁREAS PROPENSAS A INUNDAR. XXII Simpósio Brasileiro de Recursos Hídricos -ABRH, 2017.

KOBIYAMA, M. et al. Hydrological disasters reductions: lessons from hydrology. Science and Technology for Environmental Studies, 49-72, 2010.

KUWAJIMA, J. I.; FAN, F. M.; SCHWANENBERG, D.; REIS, A. A.; NIEMANN, A.; MAUAD, F. F. Climate change, water-related disasters, flood control and rainfall forecasting: a case study in river São Francisco. GEOLOGICAL SOCIETY SPECIAL PUBLICATION, 2019.

LEHNER, B.; VERDIN, K.; JARVIS, A. New Global Hydrography Derived From Spaceborne Elevation Data. EOS - v. 89, 93-94, 2008.

LOPES, V. A.; FAN, F. M.; PONTES, P. R.; SIQUEIRA, V. A.; COLLISCHONN, W.; MARQUES, D. D. A first integrated modelling of a river-lagoon large-scale hydrological system for forecasting purposes. JOURNAL OF HYDROLOGY, 177-196, 2018.

MENGUE, V. P.; SCOTTÁ, F. C.; SILVA, T. S.; FARINA, F. Utilização do Modelo HAND para mapeamento das áreas mais suscetíveis à inundação no Rio Uruguai. Pesquisas em Geociências, 41-53, 2016.

MILANESI, J.; QUADROS, E. L.; LAHM, R. A. Utilização do modelo HAND no reconhecimento dos terrenos sujeitos a inundação - Porto Alegre/RS. Revista Brasileira de Cartografia, 675-686, 2017.

MONTEITH, J. L. Evaporation and environment. Symposia of the Society for Experimental Biology, 205-224, 1965.

NASH, J. E.; SUTCLIFFE, J. V. River flow forecasting through conceptual models part I A discussion of principles. Journal of Hydrology, 282-290, 1970.

NETO, J. A.; DORNELLES, F.; FLEISCHMANN, A. S.; MEDEIROS, M. S. ESTIMATIVA DE IMPACTO DAS CHEIAS DE 1941, 1967 E 2015 EM PORTO ALEGRE NA HIPÓTESE DE INEXISTÊNCIA DO SISTEMA DE PROTEÇÃO CONTRA CHEIAS DO LAGO GUAÍBA. XXIII SIMPÓSIO BRASILEIRO DE RECURSOS HIDRÍCOS - ABRH, 2019.

NOBRE, A. D.; CUARTAS, L.; HODNETT, M.; RENNÓ, C.; RODRIGUES, G.; SILVEIRA, A.; SALESKA, S. Height Above the Nearest Drainage - a hydrologically relevant new terrain model. Journal Of Hydrology, 13-29, 2011.

O'LOUGHLIN, F. E.; PAIVA, R. C.; DURAND, M.; ALSDORF, D. E.; BATES, P. D. A multi-sensor approach towards a global vegetation corrected SRTM DEM product. Remote Sensing of Environment - v. 182, 49-59, 2016.

PAIVA, R. C.; BUARQUE, D.; COLLISCHONN, W.; BONNET, M.-P.; FRAPPART, F.; CALMANT, 
S.; MENDES, C. A. Large-scale hydrologic and hydrodynamic modeling of the Amazon River basin. Water Resource Research, 1226-1243, 2013.

PAIXÃO, M. A.; KOBIYAMA, M.; ZAMBRANO, F. C.; MICHEL, G. P.; FAN, F. M. LIÇÕES SOBRE O GERENCIAMENTO DE DESASTRES HIDROLÓGICOS OBTIDAS A PARTIR DA OCORRÊNCIA EM ROLANTE/RS. Revista Gestão \& Sustentabilidade Ambiental, 251-267, 2018.

PONTES, P. R.; COLLISCHONN, W.; FAN, F. M.; PAIVA, R. C.; BUARQUE, D. C. Modelagem hidrológica e hidráulica de grande escala com propagação. RBRH - Revista Brasileira de Recursos Hídricos, 888-904, 2015.

PONTES, P. R.; FAN, F. M.; FLEISCHMANN, A. S.; PAIVA, R. C.; BUARQUE, D. C.; SIQUEIRA, V. A.; COLLISCHONN, W. MGB-IPH model for hydrological and hydraulic simulation of large floodplain river systems coupled with open source GIS. Environmental Modelling \& Software. v. 94, 1-20, 2017.

RENNÓ, C. D.; NOBRE, A. D.; CUARTAS, L. A.; SOARES, J. V.; HODNETT, M. G.; TOMASELLA, J.; M. J. HAND, a new terrain descriptor using SRTM-DEM: Mapping terra-firme rainforest environments in Amazonia. Remote Sensing Of Environment, 3469-3481, 2008.

SIQUEIRA, V. A.; FLEISCHMANN, A. S.; FAN, F. M.; PAIVA, R. C.; PONTES, P. R.; COLLISCHONN, W. DESENVOLVIMENTO DE UM MODELO HIDROLÓGICOHIDRODINÂMICO PARA A AMÉRICA DO SUL: PARTE 1. XXII Simpósio Brasileiro de Recursos Hídricos - ABRH, 2017.

SIQUEIRA, V. A.; PAIVA, R. C.; FLEISCHMANN, A. S.; FAN, F. M.; RUHOFF, A. L.; PONTES, P. R.; COLLISCHONN, W. Toward continental hydrologic-hydrodynamic modeling in South America. Hydrology and Earth System Sciences, 4815-4843, 2018.

SPECKHANN, G. A. Mapeamento de áreas de inundação em três municípios localizados na bacia do Rio Itajaí. Trabalho de Conclusão de Curso em Engenharia Sanitária e Ambiental - UFSC. Florianópolis, SC, 2015.

TOWNSEND, P. A. Mapping seasonal flooding in forested wetlands using multi-temporal Radarsat SAR. Photogrammetric Engineering \& Remote Sensing, 857-864, 2001.

TSCHIEDEL, A. F.; PAIVA, R. C. Uncertainty Assessment in Hydrodynamic Modeling of Floods Generated by Dam Break. REVISTA BRASILEIRA DE RECURSOS HÍDRICOS; v.23, 2018.

ZHANG, F.; ZHU, X.; LIU, D. Blending MODIS and Landsat images for urban flood mapping. International Journal of Remote Sensing, 3237-3253, 2014. 